\title{
Community participation in ecotourism destinations: Maleboho Nature Reserve
}

\author{
M. P. Sebola ${ }^{1}$ \& L. de W. Fourie ${ }^{2}$ \\ ${ }^{I}$ Department of Public Management, University of Limpopo, South Africa \\ ${ }^{2}$ Tshwane University of Technology, South Africa
}

\begin{abstract}
The concept of "community participation" is regarded as a tool to assist in ecotourism and local economic development in rural communities. While the concept is arguably the best in achieving successful development objectives, there is often a missing link in its implementation process, and hence a failure to achieve the expected objective. This article, therefore, argues that community participation in Maleboho Nature Reserve cannot occur fully because of the misunderstanding among the role players as to how it should be facilitated and monitored by the government institutions. This article will, therefore, limit its relevance to the contextualisation of the concept community participation in ecotourism and the research findings at Maleboho Nature Reserve.
\end{abstract}

Keywords: community participation, ecotourism, communal nature reserve, Induna, Paramount chief.

\section{Introduction}

Kanyane [5] refers to the concept "community participation" as nothing other than community members taking part or sharing in some community activity or event. Other concepts, such as "public participation" and "civil participation," are interchangeably used to refer to community participation. It can, however, be argued that the concept may not only be limited to the active taking part in the event, but also to the effect that people have been consulted on the event, in which instance they were given the option to say" yes" or" no" to its implementation. Consultation is, therefore, an important characteristic of community participation. Consultation may not necessarily mean active participation. It may simply mean that the community might have been informed 
of the process, but may still not have been given an equal opportunity to make a decision about it. The cooperative model of rural governance stresses cooperation, communication and consultation between the local government and the traditional leaders and other institutions (Republic of South Africa [7], Republic of South Africa [9]). It is deduced from this that community participation is emphasized at various institutional levels as determined by the constitution of the country. It can, however, be further argued that while the constitution emphasises participation and consultation at various institutional levels, such processes may not be achieved if the government institution, being the upper most institution is not able to facilitate and monitor the process at various institutional levels. A properly facilitated and participative process in ecotourism development may be supported by the local communities and hence ensure the success of economic development. The exclusion of the local communities in ecotourism matters has resulted in failed projects. It is also argued here that the success of local communities in terms of the projects they identified, such as ecotourism, in their areas in order to attain job creation and poverty alleviation would depend on their level of participation and agreed management systems.

\section{Contextualising the problems of community participation and ecotourism in South Africa}

The past South African political policies of apartheid and the resulting economic decline of the established "homelands" created a situation where local people were excluded from conservation facilities, decision making processes and economic benefits generated through tourism (Christ [2]). The management styles of ecotourism destinations like the nature reserves excluded the rural communities from decision-making and economic benefits from the services of nature reserves (Republic of South Africa [8]). In such practices, which excluded the local communities from economic benefits, they were further removed from their land, and promised compensation which they never received and in many cases discouraged from entering nature reserves (Wheelan [12]).

At a public hearing on tourism which took place on the 25 June 2000, with the theme "Alleviating poverty through tourism", community based tourism organizations expressed a strong feeling that communities around the nature reserves should be encouraged to participate in the tourism development and, therefore, derive economic benefits from it (Chauke [1], Republic of South Africa [8]). Okech [6] stated that the participation of the local communities around the nature reserves in ecotourism matters would help them to be able to provide in services like hotels, restaurants, shops, transportation and guide services. It can, however, be argued that in South Africa the introduction of community participation as an approach to the development of the local communities should have long term prospects of success. The local communities have a long history of being deprived of the right to make decisions on matters affecting them. The process should, therefore, be carefully handled to transform 
the mindset of the rural local communities so that they can adapt and learn to be part of the process. The development of ecotourism destinations like game parks, national parks and nature reserves in South Africa has always meant restricted access to some groups of local and that has resulted in local communities failing to benefit from natural beauty surrounding them. This has threatened the successful implementation of ecotourism projects in the rural communities. Without them being involved, there has always been a concern within the government institutions about the snaring, poaching and deforestation. . The local communities are, therefore, an essential part of their own development and the development of any ecotourism destination has a considerable impact on their life. Community participation is required so that the particular activity can enjoy support from the local community (Eagles [3]). Local economic development is said to have been achieved with less effort where community participation was practiced than where it was ignored (Sachs [10]; Wheelan [12]; Wynne and Lynne [13]). Harrison [4] explains that, in the Republic of South Africa, there has been a progression from almost total exclusion of the local communities from decision making to a situation where they have a central and pro-active role in all issues affecting their own interest. It can, however, be argued that while South Africa is said to have shifted to civil participation in development issues, practical realities often reveal that the process of the civil participation is not properly monitored to ensure that all concerned stakeholders fully participate, and hence a continued outcry from the local communities that they are not given full decision making and participative capabilities in matters that affect them. Sebola [11] however, considers that although the concept of local participation has been widely used in the approach to modern development, care should be taken that the concept is not vulnerable to abuse in the sense that this participation may only be documented in business plans while, in reality, government officials are still making decisions on their own. That being the case, it would suggest a deception in modern democracy and in the development of the rural communities.

\section{Reflecting the community participation structure}

Much has been written about how community participation can enhance local economic development. It can, however, also be argued that not much has been written about how a failure to develop good criteria to apply this concept has resulted in the poor achievement of development objectives. A simplified community participation structure is based on three levels: Government, community structures and local community. The structure uses a top-down approach system. The consultation is between the government structures and those representing the local communities. A deadlock, whether representative of the local community or not, may affect their participation. A tentative involvement by the structure representing the local communities would impact on the local participation and yet the government structure will claim that they indeed consulted with the community structures. 


\section{Local communities around Maleboho Nature Reserve}

The population sample of the local communities around Maleboho Nature Reserve is estimated at 4679 according to the Office of Statistics South Africa, Limpopo Province. The nature reserve is surrounded by the following four villages and their population sample is distributed as follows: Mydarling 2220 , Burgerecht 2 040, Setloking 79 and Ga- Kgatla 340.

\subsection{Research objective}

The purpose of the research was to determine whether the local communities around the Maleboho Nature Reserve are able to remember the year the nature reserve was established, whether consultation took place when the nature reserve was established, whether the local communities presently participate in the management of the nature reserve, and whether the local community structures report to the local communities on nature reserve activities.

\subsection{Research methodology}

The researcher distributed 491 questionnaires to the local communities around the nature reserve. Data from other sources such as government institutions, community structures were obtained by means of unstructured interviews and such information was used in this research to add or confirm data obtained through structured questionnaires.

\subsection{Research findings and discussion}

The findings of the research in terms of community participation in the Maleboho Nature Reserve probed the following four aspects of community participation in the nature reserve: Remembering the year when the nature reserve was established, consultation and participation in the nature reserve management, and continuous feedback from the community structures. The honest response from members of the local communities in this regard determines whether community participation was properly obtained in the nature reserve and whether it is presently elicited aimed at achieving and benefiting the local communities in terms of local economic development. The research findings and discussions are presented as follows:

\subsubsection{Remembering the year the nature reserve was established}

The respondents were required by means of a questionnaire to respond to whether members of the local communities are able to remember the year the nature reserve was established. Their response to this question is to determine if participation took place when the nature reserve was established. If it is determined that the local communities can remember the year the nature reserve was established, it can be assumed that they knew about its establishment. The critical question on this issue is, however, not about remembering the year the nature reserve was established, but whether the local communities were made to participate in the decision making in that regard. The local communities responded as follows: 


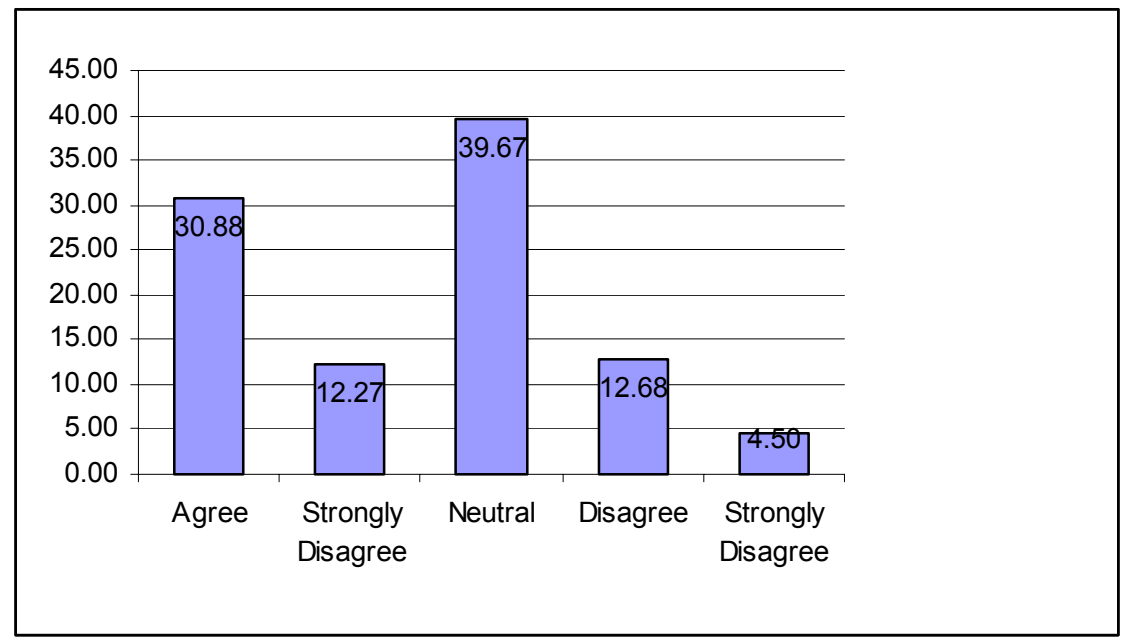

Figure 1: Response rate about remembering the year the nature reserve was established.

The largest group of respondents $(42.15 \%)$ is of the opinion that members of the local communities around the nature reserve can remember the year the nature reserve was established. The second largest group of respondents $(39.67 \%)$ chose to be neutral. Only $(17.18 \%)$ of the members of the local communities are of the opinion that the local communities around the nature reserve cannot remember the year the nature reserve was established. It can be deduced that the majority of the respondents who chose to be neutral are a group of student respondents who were very young when the nature reserve was established. It is also possible that the largest group of respondents, who are of the opinion that the locals can remember that year, does not agree that participation took place. The largest group of respondents $(42.15 \%)$ may be a group of middle aged people and people from the older generation in the village who remember the year the nature reserve was established. The members of the local communities have different experiences of remembering the period. Most remember it as the time a message was disseminated among the members of the local communities through the Indunas that any member of a local community approaching the identified protected area shall be guilty of an offence and shall be punished. In remembering that year a senior member of the Kgatla clan said: "That is the year that our cattle were fenced inside the nature reserve, and we were given short notice to remove them, and warned that they will be shot dead by the government officials if not quickly removed. I personally had to leave my work in Johannesburg for that purpose - but to no avail as most of our cattle were shot dead before we could remove them". The remembering of the year of the establishment of the nature reserve is not remembered as a year that the local communities participated in its establishment, but rather as the year that inaugurated their exclusion from the nature reserve and the denial of their right to utilize their natural resources for either tilling or grazing. 


\subsubsection{Consultation}

The local communities around the Maleboho Nature Reserve responded as follows as to whether they were consulted on the establishment of the nature reserve:

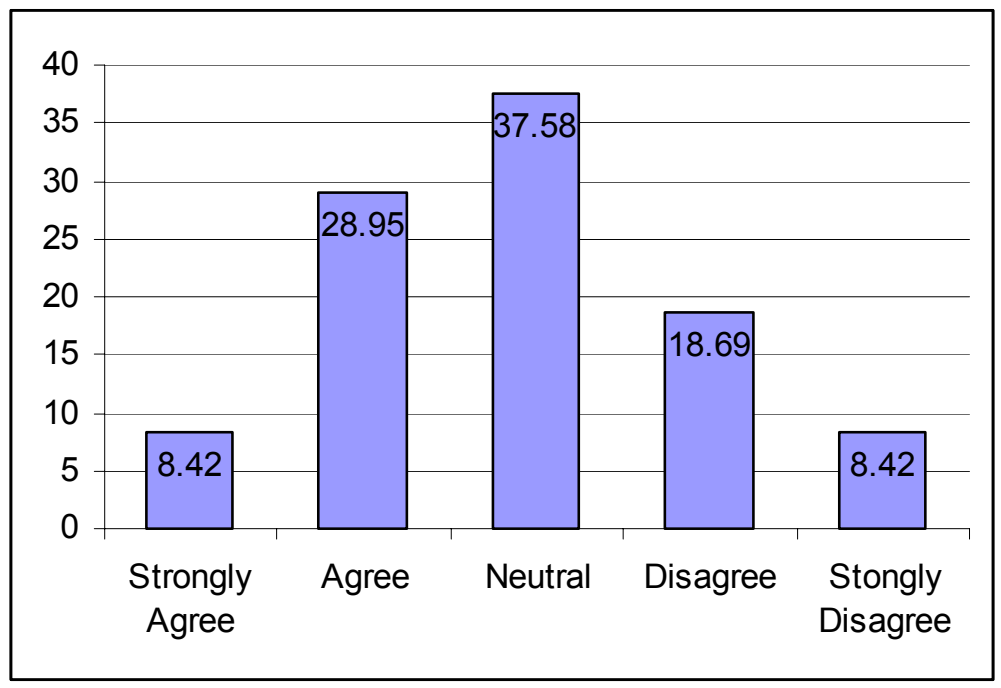

Figure 2: Response rate as to whether consultation was done in establishing the nature reserve.

It is notable from the graph above that the largest percentage of the respondents $(37.37 \%)$ is of the opinion that sufficient consultation took place when the nature reserve was established. Only (27.11\%) of the local communities are of the opinion that sufficient consultation did not take place. $(37.58 \%)$ of the respondents chose to be neutral on the issue. It can be deduced that this percentage represents the category of the student respondents. Such respondents could neither agree nor disagree on the question because most of them were either too young when the nature reserve was established in 1981 or they were not in the area when it was established. Hence they would not know if consultation took place. The concept of consultation and participation may mean different things to different people. Most of the respondents, while agreeing that they were consulted, also argue that the process was not by means of participative consultation. They argue that it was simply information from the paramount chief, given to the affected local communities, informing them of the project to be undertaken, and that members of the local communities were to remove themselves from the identified area. Failure to comply would ensure that the offenders incur heavy fines from the tribal court. In this instance it is deduced that the establishment of the nature reserve was imposed on the local communities. Interactive participation was not encouraged in the process and the local communities were to accept the project which involved the government 
structures and the traditional leadership only. The government institution, being a top structure to implement projects in communities may argue that consultation and participation took place when Maleboho Nature Reserve was established. Government institutions will always argue that in implementing projects they do not have direct interaction with the local communities. At Ga-Kgatla, the Induna said: "We were never consulted about the establishment of this nature reserve. We just saw people coming in here to our village, planted poles and fenced around us... the village we are in now was initially in the nature reserve... people just fenced us in for conservation without a word with us..." In this instance it can be deduced that consultations indeed took place with the land owner who, in this instance, was the paramount chief and not the Induna of the tribe. The institution of the paramount chief is, therefore, regarded as the local government in the rural areas and consultations are with that institution. It is, therefore, argued that while community participation can be enhanced at a certain level between the government institution and the tribal leadership, second level structure facilitation with the local communities at grassroots level cannot be guaranteed.

\subsubsection{Community participation in the nature reserve}

The local communities around the nature reserve were surveyed as to whether they participated in the nature reserve and were allowed to make inputs on the running of the nature reserve. The members of the local communities responded as follows:

Table 1: Response rate regarding community participation in the nature reserve.

\begin{tabular}{|l|c|c|c|c|}
\hline $\begin{array}{l}\text { Response } \\
\text { Category }\end{array}$ & Frequency & Percent & $\begin{array}{c}\text { Cumulative } \\
\text { Frequency }\end{array}$ & $\begin{array}{c}\text { Cumulative } \\
\text { Percent }\end{array}$ \\
\hline $\begin{array}{l}\text { Strongly } \\
\text { Agree }\end{array}$ & 66 & 13.50 & 66 & 13.50 \\
\hline Agree & 131 & 26.79 & 197 & 40.29 \\
\hline Neutral & 59 & 12.07 & 256 & 52.35 \\
\hline Disagree & 148 & 30.27 & 404 & 82.62 \\
\hline $\begin{array}{l}\text { Strongly } \\
\text { Disagree }\end{array}$ & 83 & 17.38 & 489 & 100.00 \\
\hline
\end{tabular}

It is notable from the above table that $40.29 \%$ of the members of the local communities around the Maleboho Nature Reserve are of the opinion that the members of the local communities around the nature reserve are given the opportunity to participate in the nature reserve's management. The largest percentage of the respondents $(47.65 \%)$ is of the opinion that members of the local communities around the nature reserve are not given the opportunity to 
participate in the nature reserve's management. The second category of the largest respondents supports the common theory of community participation that the local communities around the nature reserve are denied participation and decision making. The issue of community participation in this regard is also ambiguous. There is a notable perception from the respondents that those who recognize the role of the Community Tourism Trust, irrespective of whether they receive feedback from that committee, believe that they are equally represented in the management. Those respondents who see the Community Tourism Trust as a puppet of the nature reserve management disagree that there is any local participation in the nature reserve.

The manager at Maleboho Nature Reserve confirmed the ambiguity of local participation through community structures when he said:" We do not have a direct interaction with the local communities at large on nature reserve matters. The local communities are represented through the local tourism trust. We as a nature reserve management established a Community Tourism Trust composed of members of the local communities". As the interview unfolded, it became apparent that the Community Tourism Trust in this nature reserve does not represent the respective local communities around the nature reserve. The members of the Community Tourism Trust are in the nature reserve to perform honorary ranger portfolios to assist the nature reserve rangers to identify the poachers in their respective villages or members of the local villages contravening conservation laws so that they can be arrested. This has often led to members of the Community Tourism Trust being hated by the local communities because of their role as puppets in nature conservation. It is also deduced from its role that the members of the Community Tourism Trust are co-opted on to the committee by the nature reserve's management rather than being proposed by the local communities. The nature reserve's management is able to disband and establish new committees from time to time as they wish. This happens mostly because the proposed members to the committee do not know exact scope of their responsibilities. In some instances this is also influenced by the literacy level in the rural communities. Subsequently, members of the Community Tourism Trust do not have an effective role in the nature reserve's management and their representation of the local communities in the nature reserve becomes null and void.

\subsubsection{Feedback from the Community Tourism Trust}

A Community Tourism Trust is a structure that represents the local communities' in natural attractions. The presence of such a structure in the local communities' adjacent to the nature attractions shows that the local communities are provided with feedback on the activities of the nature reserve. The local communities around the Maleboho Nature Reserve were surveyed to determine whether they obtain feedback from the Community Tourism Trust to ensure their participation through that structure. They responded as follows:

The pie graph shows that $39 \%$ of the local communities around the nature reserve are of the opinion that members of the Community Tourism Trust provide continuous feedback to the local communities about the activities of the 
nature reserve. The largest percentages of the respondents $(51 \%)$ around the nature reserve are of the opinion that the Community Tourism Trust does not provide feedback on the activities of the nature reserve. It, therefore, implies that the Community Tourism Trust in the Maleboho Nature Reserve does not represent the local communities in that management. Failure by the Community Tourism Trust to provide continuous feedback to the local communities may mean two things: firstly, that the Community Tourism Trusts does not understand its role and responsibilities in nature reserve matters. Secondly, that the Community Tourism Trust is unable to clarify its role to the members of the local communities and hence the local communities feel misrepresented.

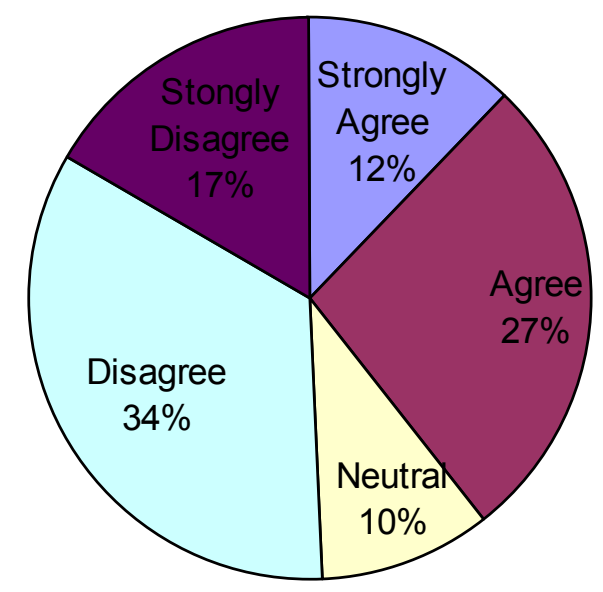

$\square$ Strongly Agree

Agree

$\square$ Neutral

$\square$ Disagree

口 Stongly Disagree

Figure 3: Response rate regarding feedback obtained from the Community Tourism Trust.

\section{A proposed workable model to facilitate community participation}

This article argues that community participation takes place at three levels and the role players at every level are to be aware of the project. Each level has different stakeholders. This article does, however, argue that the second level, which mostly involves community structures, is responsible for the failure of the successful implementation of community participation process. In the case of ecotourism, the article proposes the following model as a solution to the lack of community participation.

The argument of this model regarding community participation is that, while community participation is facilitated through government institutions and filtered down to the local communities through community structures, there has 
always been a lack of facilitation in that regard. It is argued that the government has only considered the community structures for these purposes. Whether the community structures are able to deliver the message to the local communities was never given much consideration. The government institution is to ensure that the local communities are practically involved. There is a need for monitoring to ensure that the project is not only known to the government institution and community structures, but also to the people at the grassroots level. It is often argued that both the government institutions and community structures may often take decisions that are not popular with the people at grassroots' levels. Community participation is to be representative of the local communities. The community structures are to represent the local communities rather than individual wishes.

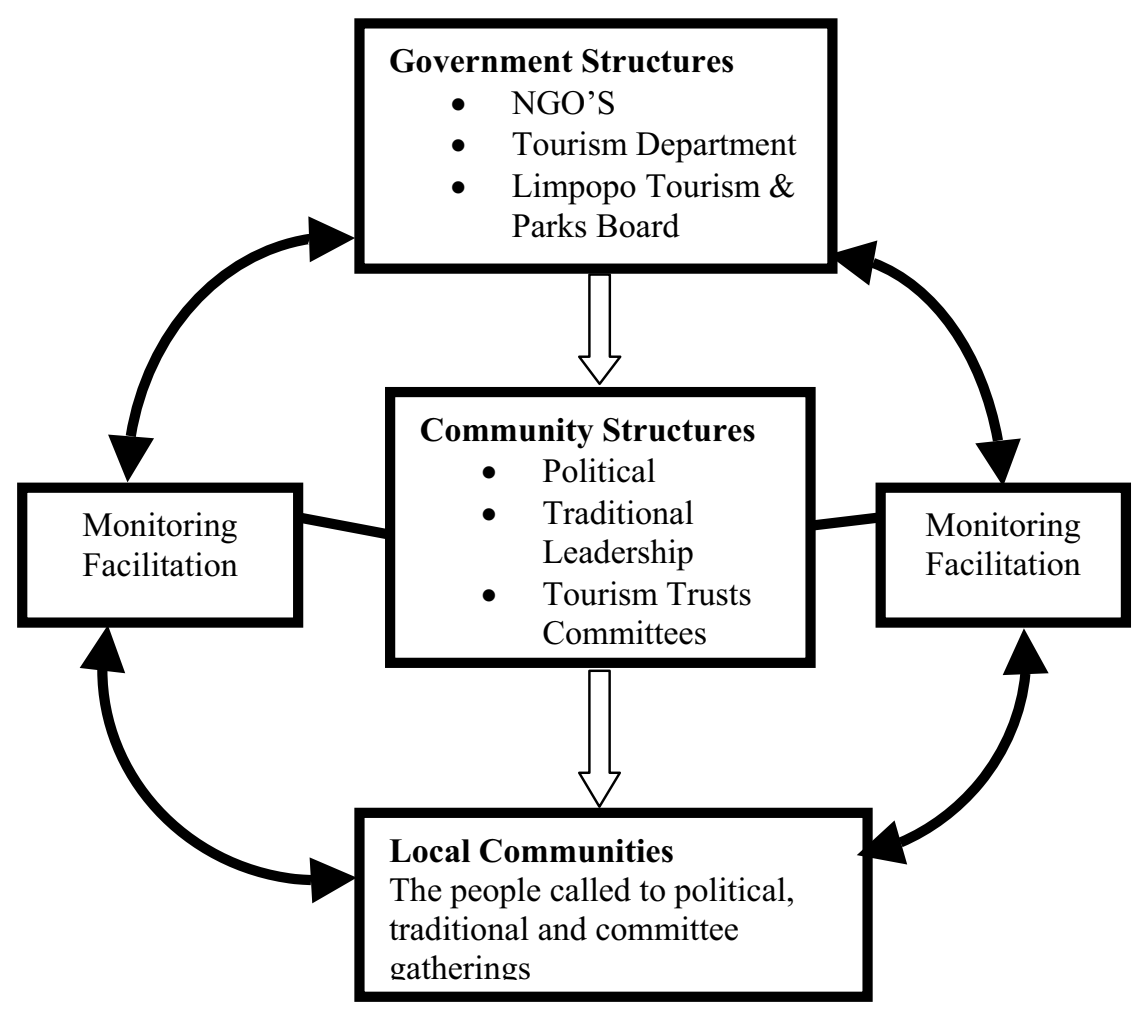

Figure 4: $\quad$ A proposed community participation model.

\section{Conclusion}

The article captured issues on the problems of community participation in Maleboho Nature Reserve. The research findings at Maleboho Nature Reserve established that there is a missing link in facilitating community participation. It 
is observed that the concept of community participation is understood differently at both structural and institutional levels, levels at which all structures believe they have played their roles except the local communities at grassroots level. The government institution being the top structure was not seen to be monitoring the process of community participation to ensure that the community structures really communicate the government issues to the local communities. The reality of the situation in this regard indicates that thus far the middle-level structure which is the community structures prohibits local participation. This article proposed a community participation model to ensure that local communities at grassroots are able to participate through a monitored process by the government institutions.

\section{References}

[1] Chauke, P., Public hearing on tourism. Legistalk. Vol 4 no.2. Newsletter for the Legislature of the Northern Province, pp.5 2000.

[2] Christ, C., Conservation cooperation: Ecotourism through rural investment. Bateleur house. Sandton, pp1-3,ndp.

[3] Eagles, P.F.J., International ecotourism management: Using Australia and Africa as Case studies. (Available on internet) www.ahs.uwaterloo.ac

[4] Harrison D., Tourism and the less Developed World. Issues and case studies, Cabi publishing. United Kingdom, pp.214, 2001

[5] Kanyane M.H. Community participation in Policing (Chapter 5). Cases in Public administration and management: A South African perspective, eds. M.J Mafunisa and M.H Maserumule. Heinemann publishers, pp.95.

[6] Okech, R. N. Sustainable ecotourism and local communities: Cooperation, compromise or conflict? Ecotourism Society of Kenya. Upperhill, pp.3, 2005.

[7] Republic of South Africa, Constitution of the Republic of South Africa. Act 108 of 1996. Cape Town Government Printer, pp.93, 1996

[8] Republic of South Africa. Green paper on Environmental Policy for South Africa. Pretoria. Government Printer, pp.15, 1996.

[9] Republic of South Africa, White Paper on Local Economic Development. Pretoria. Government Printer, pp. 97-98, 1998.

[10] Sachs, W. The Development Dictionary. A guide to knowledge as power. Zed books limited. London.1993

[11] Sebola M.P 2003:The communal nature reserves: A concern for development in Limpopo province. Journal of public administration, pp 476- 484. 38 (4) 2003.

[12] Wheelan, T. Nature tourism. Managing the Environment. Island press. Washington D.C, pp.15, 132-133,1991.

[13] Wynne, A and M.C Lynne, Communities, institutions and natural resources: An assessment of case studies from Kwa-Zulu Natal. Development Southern Africa, pp 649-667. 12(5) October 1995. 